\title{
Efektifitas Keputusan Manajemen Dalam Penilaian Kinerja Karyawan Menerapkan Metode Weigthed Product (WP)
}

\author{
Tri Widayati ${ }^{1}$, Nugroho Sumarjiyanto Benedictus Maria ${ }^{2, *}$ \\ ${ }^{1}$ Fakultas Ekonomika dan Bisnis, Universitas 17 Agustus 1945 Semarang, Indonesia \\ ${ }^{2}$ Fakultas Ekonomika dan Bisnis, Universitas Diponegoro, Semarang, Indonesia \\ Email: ${ }^{1}$ triwiedy33@ gmail.com, ${ }^{2}$ nugrohosbm@ lecturer.undip.ac.id \\ Email Penulis Korespondensi nugrohosbm@lecturer.undip.ac.id
}

\begin{abstract}
Abstrak-Penilaian kinerja terhadap karyawan merupakan hal yang penting untuk dilakukan oleh instansi pemerintahan maupun perusahaan swasta berguna untuk melihat, memonitoring tingkat dan kualitas kerja yang diberikan oleh seseorang karyawan terhadap perusahaannya guna menciptakan perusahaan yang mampu mencapai tujuan yang dimiliki masing-masing perusahaan dengan memulai melakukan evaluasi terhadap SDM (Sumber Daya Manusianya) karena dalam dunia bisnis dan manajemen mengatakan bahwa perusahaan yang hebat yaitu perusahaan yang mampu memanajemen sumber daya manusianya. Dalam penilaian kinerja karyawan tiap perusahaan memiliki caranya masing-masing dan pastinya berbeda-beda dalam praktek nyata kegiatan penilaian kinerja karyawan ini haruslah dilakukan dengan baik dan seadil-adilnya untuk menghilangkan kesenjangan sosial dalam dunia kerja dan mengurangi terjadinya kesalahan dalam pemberian penilaian terhadap kinerja masing-masing karyawan perusahaan dan hasil yang didapatkan setelah karyawan diberikan penilaian terhadap kinerjanya diharapkan dapat menumbuhkan dan berpengaruh pada tingkat loyalitas yang diberikan oleh karyawan terhadap perusahaan dan menumbuhkan motivasi diri yang tinggi untuk kemajuan perusahaan itu sendiri. Dalam penilaian kinerja karyawan terdapat beberapa alat bantu yang bisa digunakan salah satunya berupa sistem pendukung keputusan yang nantinya akan mengolah beberapa kriteria yang telah ditetapkan perusahaan menggunakan metode Weighted Product (WP).
\end{abstract}

Kata Kunci: Kinerja Karyawan, SPK, Weighted Product (WP).

Abstract-Performance appraisal of employees is an important thing to do by government agencies and private companies. It is useful to see, monitor the level and quality of work given by an employee to his company in order to create a company that is able to achieve the goals of each company by starting to do evaluation of HR (Human Resources) because in the business and management world says that a great company is a company that is able to manage its human resources. In employee performance appraisal, each company has their own way and certainly different in the actual practice of employee performance appraisal activities must be done properly and fairly as possible to eliminate social gaps in the world of work and reduce the occurrence of errors in granting an assessment of the performance of each each company employee and the results obtained after employees are given an assessment of their performance are expected to grow and influence the level of loyalty given by employees to the company and foster high self-motivation for the progress of the company itself. In evaluating employee performance, there are several tools that can be used, one of which is a decision support system that will process some of the criteria set by the company using the Weighted Product (WP) method.

Keywords: Employee Performance, SPK, Weighted Product (WP).

\section{PENDAHULUAN}

Pada era globalisasi dunia saat ini dimana teknologi menggengam aspek-aspek penting dalam kehidupan seharihari dan mempermudah setiap pekerjaan manusia dengan mengambil alih fungsi pekerjaan manusia yang sudah bisa dikerjakan dan dilakukan oleh berbagai jenis teknologi, peranan teknologi banyak membantu manusia dalam kehidupan sehari-hari. Teknologi tidak hanya berperan dalam membantu setiap pekerjaan manusia tetapi teknologi juga berperan dan ikut serta dalam kemajuan ekonomi dunia termasuk setiap kegiatan perekonomian baik nasional maupun internasional[1].

Indonesia juga merupakan salah satu dari banyak negara yang sudah menggunakan teknologi dalam mempermudah pekerjaan manusia dalam sektor usaha atau perdagangan dan perusahaan-perusahaan berskala besar, kemajuan yang dicapai sebuah perusahaan merupakan salah satu tujuan dari setiap perusahaan, sebuah perusahaan yang maju dan terus berkembang akan memberi dampak baik bagi negara juga seperti mengurangi tingkat pengangguran di negara dan mengurangi tingkat kemiskinan negara dan semakin banyak perusahaan yang maju dan berkembang semakin baik lah negara tersebut.

Dalam sebuah organisasi SDM (Sumber Daya Manusia) merupakan suatu unsur yang paling penting, tanpa peran manusia maka apaun unsur yang ada didalam sebuah organisasi baik itu teknologi tidak akan bisa menggantikan manusia karena manusia yang mengontrol dan manajemen suatu organisasi itu, dan suatu organisasi yang maju dan berkembang serta mampu bertahan dalam segala keadaan merupakan organisasi yang memiliki manager yang mampu manajemen sebuah organisasi atau perusahaan dan karyawan. Maka dari itu dibutuhkan upaya untuk meningkatkan kualitas sumber daya manusia[2].

Penilaian kinerja karyawan merupakan salah satu cara baik untuk meningkatkan mutu kerja dari karyawan perusahaan dan juga merupakan salah satu cara mengevaluasi kinerja dari setiap perusahaan. Kinerja atau performance dan disebut juga dengan tampilan dan usaha kerja yang telah diberikan karyawan terhadap perusahaannya, kinerja itu juga disebut dengan suatu kegiatan dan cara kerja ataupun bertindak dalam melakukan kegiatan fungsi organisasinya. Sehingga dapat disimpulkan bahwa kinerja itu adalah hasi kemampuan usaha 
maupun kerja seseorang baik secara kualitas maupun kuantitas dan diupayakan untuk mencapai suatu tujuan yang sudah ditetapkan dalam priode waktu tertentu.

Penilaian kinerja karyawan itu sendiri diharapkan dapat memotivasi setiap karyawan untuk terus meningkatkan dan memotivasi diri untuk bekerja dengan baik dan memiliki rasa cinta terhadap perusahaan yang berpengaruh baik bagi perusahaan sehingga membuat rasa kerja yang nyaman dan memiliki kerja sama tim yang kompak dan tercapainya tujuan suatu perusahaan itu tercapai. Perusahaan selama ini menilai kinerja karyawan hanya melihat dari daftar hadir karyawan dan diangga tidak efektif dalam penilaiannya, banyak karyawan yang mengharapkan pengambilan nilai terhadap kinerja karyawan dilakukan dengan cara seadil-adilnya tidak berdasarkan dari satu kriteria[3].

Biasanya pengambilan dan pembuatan data menggunakan cara manual yaitu mencatat setiap kegiatan yang dilakukan oleh tiap karyawan, data karyawan yang sangat banyak membuat proses pendataan dan penilaian kinerja karyawan menjadi sedikit terhambat dari sering terjadi kesalahan input data dan waktu yang dibutuhkan sangat lama, maka dari itu dibutuhkan alat untuk membantu pihak perusahaan dalam menilai kinerja karyawan itu sendir dengan menggunakan suatu sistem koputerisasi agar dalam pengambilan keputusan yang didapatkan adalah keputusan yang mutlak berdasarkan sistem.

Sistem Pendukung Keputusan (SPK) merupakan salah satu alat yang digunakan dalam pengambilan keputusan yang bersifat terstruktur dan penting yang diambil berdasarkan kriteria-kriteria yang telah ditetapkan sebelumnya untuk mendukung atau sebagai syarat penilaian kinerja karyawan terhadap suatu perusahaan[4]-[6]. Sistem pendukung keputusan ini sendiri merupakan sebuah sistem komputer yang dirancang dan dibuat dalam bentuk sebuah sistem atau aplikasi yang dapat digunakan untuk menginput data kandidat dan kriteria untuk penilaian kinerja karyawan dan diproses dengan sistem komputerisasi sehingga permasalahan penginputan data secara manual dan kesalahan yang dapat terjadi dalam penginputan data secara manual dan memakan waktu yang lama akan sedikit berkurang, dalam sistem pendukung keputusan penulis menggunakan pendekatan untuk menyelesaikan masalah penilaian kinerja karyawan dengan menggunakan metode Weighted Product (WP)[7].

Penelitian sebelumnya menunjukkan beberapa pendekatan metode dalam membantu pengambilan keputusan terhadap suatu penilaian baik penilaian pemberian reward, pemilihan kepala daerah, pemilihan atau penentuan duta kampus, pemilihan siswa berrestasi dan banyak lainnya, metode pendekatan tersebut antara lain metode Promethe 2, metode MOORA, TOPSIS, Simple Additive Weighting [8], [9].

Dalam penelitian ini penulis menggunakan metode Weighted Product (WP), metode ini mengambil keputussan berdasarkan nilai akumulasi dari normalisasi kriteria berdasarkan nilai tertinggi akhir yang didapatkan dalam menggunakan metode Weighted Product (WP), metode ini dianggap metode yang paling simple dan mudah untuk dipahami dan digunakan dan dapat digunakan untuk membantu dalam pengambilan keputusan lainnya[10].

Hasil penelitian ini diharapkan mampu memberikan dampak positif bagi pihak-pihak yang bersangkutan dan memberikan manfaat berupa teoristis dan manfaat praktisi dan secara umum dapat membantu dalam keputusan manajemen terutama dalam manajemen sumber daya manusia, dengan penelitian ini dapat mengevaluasi dan menjadi motivasi tiap karyawan untuk meningkatkan kinerja karyawan yang optimal.

\section{METODOLOGI PENELITIAN}

Penelitian ini merupakan penelitian kuantitatif, penelitian kuantitatif merupakan penelitian secara ilmiah yang dilakukan berdasarkan hubungan-hubungan dan fenomena yang terjadi dalam penelitian, penelitian ini menghubungkan antara variable-variabel dalam sebuah populasi dan pengukuran dilakukan berdasarkan data kuantitatif, tujuann dari penelitian ini adalah untuk mengembangkan dan menggunakan terori-teori dalam model matematis. Dalam penelitian ini nantinya akan dikembangan setelah mendapatkan hasil berupa penilaian kinerja karyawan dapat dikembangan sistem berupa sistem informasi dalam penerapan pengambilan keputusan berikut ini merupakan gambaran dalam pengembangan sistem[11].

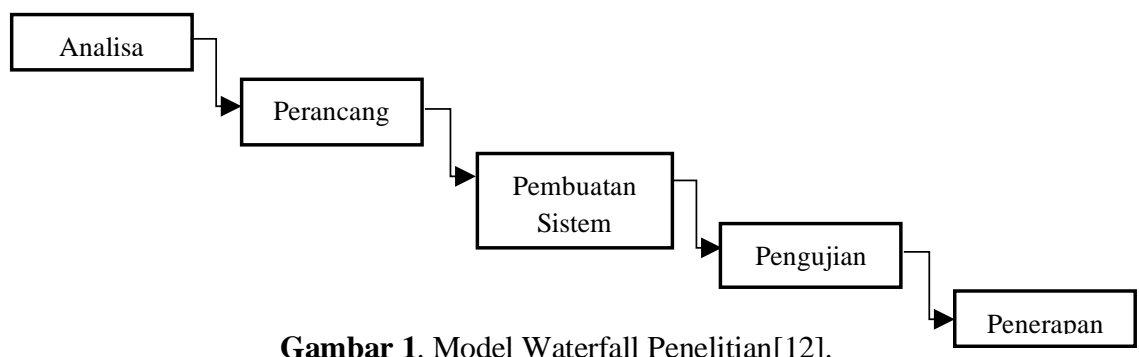

\subsection{Pengumpulan Data}

Dalam sebuah peneitian dibutuhkan data, data merupakan hal yang penting dalam sebuah peneltian tanpa sebuah data sebuah penelitian tidak bias dilakukan berikut ini merupakan tahapan pengumpulan data yang dilakukan peneliti dalam penilaian kinerja karyawan [13]: 
1. Observasi

Untuk melihat apa-apa saja aspek yang menjadi penilaian terhadap kinerja dari masing-masing karyawan karena setiap perusahaan pasti memiliki kriteria dan cara memberikan penilaian tersendiri berdasarkan apa yang menjad tujuan perusahaan.

2. Wawancara

Dalam metode ini dilakukan wawancara (interview) dengan cara penulis mengajukan beberapa pertanyaan yang berhubungan terhadap perusahaan dalam penilaian kinerja karyawan, hasil bias dalam bentuk video, perekaman suara dan tulisan, dan dapat disimpan sebagai bukti nyata dari sebuah penelitian

3. Studi kepustakaan

Dalam metode ini mengumpulkan data-data pendukung dalam penulisan penelitian, dan penulis menggunakan buku-buku, jurnal sebagai literature review dalam mempelajari kembali matode Weighted Product (WP)

\subsection{Metode Weighted Product (WP)}

Metode Weighted Product (WP) dapat membantu dalam penilaian kinerja karyawan, penilaian yang dianggap mutlak dan berhasil merupakan penilaian yang memiliki angka tertinggi dan itu menunjukan sebagai alternatif atau kandidat terbaik, peneliti memilih metode Weighted Product (WP) dalam hal ini Karena metode ini merupakan metode yang cukup sederhana dan pengerjaannya yang singkat sehingga lebih efisien mulai dari pengerjaan dan perhitungan yang memakan waktu yang singkat dalam pembobotan juga terdapat nilai atribut Benefit (keuntungan) berfungsi sebagai nilai pangkat yang positif dan nilai Cost (biaya) berfungsi sebagai nilai pangkat yang negative.

Dalam mencari nilai kinerja karyawan menggunakan metode Weighted Product (WP) terdapat beberapa langkah-langkah perhitungan sebagai berikut[5], [14]:

1. Tentukan kriterian dan lakukan pembobotan kriteria

2. Memberikan nilai criteria $(\mathrm{Ci})$ yang dimiliki setiap alternative (Ai) dimana nilai $\mathrm{i}=1,2,3 \ldots \mathrm{m}$.

3. Lakukan perbaikan terhadap bobot agar dapat menghasilkan nilai $\sum W_{j}=1$ menggunakan persamaan menggunakan rumus:

$$
W_{j}=\frac{W}{\sum W}
$$

4. Tentukan nilai vektor $\mathrm{S}$ yaitu dengan cara semua kriteria (Ci) dikalikan dengan bobot yang sudah diperbaiki. Dalam menentukan nilai vektor $\mathrm{S}$ digunakan rumus:

$$
S_{i}=\prod_{j}^{n} X_{i_{j}}^{w_{j}}
$$

5. Untuk nilai Ranking terbaik, digunakan rumus sebagai berikut ini:

$\begin{array}{cl}\text { Keterangan dari semua rumus: } \\ \text { S } & \text { : Menyatakan Preferensi Alternatif (Vektor S) } \\ \text { X } & \text { : Nilai Kriteria } \\ \text { W } & \text { : Bobot Kriteria } \\ \text { I } & \text { : Menyatakan Alternatif } \\ \text { J } & \text { : Menyatakan Kriteria } \\ \text { N } & \text { : Menyatakan Banyaknya Kriteria } \\ \text { V } & \text { : Preferensi Alternatif (Vektor V) }\end{array}$

$$
V_{i}=\frac{S_{i}}{\prod_{j=1}^{n}\left(x_{j}^{*}\right)^{w j}}
$$

\section{HASIL DAN PEMBAHASAN}

Analisa ini menggunakan beberapa krtiteria dimana kriteria tersebut didapatkan oleh pihak melalui beberapa proses dan masukan dari jurnal, internet dan buku dalam peninjauan, pengembangan dan peningkatan kinerja karyawan terhadap sebuah perusahaan, dari beberapa informasi yang ditemukan terdapat banyak pertanyaan dan pernyataan yang menunjukan bahwa seorang karyawan yang memiliki kinerja yang baik, harus memenuhi beberapa pertanyaan yang panjang sebanyak 20-50 pertanyaan sehingga membuat dalam pengambilan data akan menyebabkan tidak efisiennya dan banyak menghabiskan waktu dan tenaga[15].

Maka dari itu dalam pengambilan penilaian kinerja karyawan perusahaan mengambil beberapa jenis pertanyaan yang menjadi krieria karyawan sebagai salah satu cara untuk menganalisa dan menilai kinerja karyawan tetap dengan metode Weighted Product (WP), penilaian ini digunakan hanya untuk pekerja yang sudah berstatus karyawan tetap dan dari berbagai jenis jabatan dalam satu kantor cabang Weighted Product (WP).

Sebelum melakukan analisa menggunakan metode Weighted Product (WP), telebih dahulu harus ada kandidat atau peserta sebagai alternatif atau bahan penilaian, tentunya dari nama-nama karyawan Weighted Product (WP), kriteria yang sudah dipilih pihak Weighted Product (WP) dan dianggap sebagai bahan pertimbangan yang pas dalam pemilihan yang diinginkan pihak perusahaan, tentukan nilai terhadap masingmasing kriteria yang dimiliki tiap alternatif dan lakukan perhitungan menggunakan metode Weighted Product (WP)[16]. 
JURNAL MEDIA INFORMATIKA BUDIDARMA

Volume 4, Nomor 3, Juli 2020, Page 612-617

ISSN 2614-5278 (media cetak), ISSN 2548-8368 (media online)

Available Online at https://ejurnal.stmik-budidarma.ac.id/index.php/mib

DOI 10.30865/mib.v4i3.2176

Berikut ini merupakan analisa dengan menggunakan metode Weighted Product (WP):

Tabel 1. Alternatif

\begin{tabular}{cc}
\hline Kode & Nama Alternatif \\
\hline A1 & Riana \\
A2 & Desi Ismira \\
A3 & Muhammad Ferdi \\
A4 & Raka Aditya \\
A5 & Dicky Mardianto \\
A6 & Putri Shefira R \\
A7 & Afiansyah Damanik \\
A8 & Ririn Ocktavia \\
A9 & Feri Irwansyah \\
A10 & Armansyah Lubis \\
A11 & Kiki Armi \\
A12 & Santo Sidabutar \\
A13 & Fachri Ramadhan \\
A14 & Abdul Hanif \\
A15 & Afdal \\
\hline
\end{tabular}

Tabel 2. Kriteria dan bobot

\begin{tabular}{clcc}
\hline kriteria & \multicolumn{1}{c}{ Nama } & Keterangan & Bobot \\
\hline C1 & Loyalitas (L) & Benefit & $15 \%$ \\
C2 & Produktivitas Dan Kualitas Kerja (PKK) & Benefit & $10 \%$ \\
C3 & Kemampuan Mengatasi Masalah (KMK) & Benefit & $15 \%$ \\
C4 & Kemauan Belajar (KB) & Benefit & $10 \%$ \\
C5 & Kerja Sama (KS) & Benefit & $10 \%$ \\
C6 & Menjaga Kebersihan, Keselamatan Kerja (K3) & Benefit & $15 \%$ \\
C7 & Tanggung Jawab (TJ) & Benefit & $10 \%$ \\
C8 & Disiplin (D) & Benefit & $15 \%$ \\
\hline
\end{tabular}

Tabel 3. Angka Penilaian Terhadap Kriteria

\begin{tabular}{lc}
\hline \multicolumn{1}{c}{ Keterangan } & Nilai \\
\hline Sangat Baik (SB) & 5 \\
Baik (B) & 4 \\
Cukup Baik (CB) & 3 \\
Buruk (B) & 2 \\
Sangat Buruk (SBK) & 1 \\
\hline
\end{tabular}

Tabel 4. Data Alternatif dan Kriteria

\begin{tabular}{|c|c|c|c|c|c|c|c|c|}
\hline \multirow{2}{*}{ Alternatif } & \multicolumn{8}{|c|}{ Kriteria } \\
\hline & $\mathbf{L}$ & PKK & KMK & KB & $\mathbf{K S}$ & K3 & TJ & D \\
\hline Riana & $\begin{array}{c}\text { Sangat } \\
\text { Baik }\end{array}$ & $\begin{array}{c}\text { Cukup } \\
\text { Baik }\end{array}$ & Baik & Baik & Baik & $\begin{array}{c}\text { Cukup } \\
\text { baik }\end{array}$ & Baik & Baik \\
\hline Desi Ismira & $\begin{array}{c}\text { Sangat } \\
\text { Baik }\end{array}$ & Baik & $\begin{array}{l}\text { Sangat } \\
\text { Baik }\end{array}$ & Baik & $\begin{array}{c}\text { Sangat } \\
\text { Baik }\end{array}$ & $\begin{array}{c}\text { Sangat } \\
\text { Baik }\end{array}$ & $\begin{array}{c}\text { Cukup } \\
\text { baik }\end{array}$ & $\begin{array}{c}\text { Sangat } \\
\text { Baik }\end{array}$ \\
\hline Muhammad Ferdi & Baik & $\begin{array}{c}\text { Sangat } \\
\text { Baik }\end{array}$ & $\begin{array}{c}\text { Sangat } \\
\text { Baik }\end{array}$ & $\begin{array}{c}\text { Sangat } \\
\text { Baik }\end{array}$ & Baik & Buruk & $\begin{array}{l}\text { Cukup } \\
\text { baik }\end{array}$ & Baik \\
\hline Raka Aditya & Baik & Baik & $\begin{array}{c}\text { Sangat } \\
\text { Baik }\end{array}$ & Baik & $\begin{array}{l}\text { Cukup } \\
\text { baik }\end{array}$ & $\begin{array}{c}\text { Sangat } \\
\text { Baik }\end{array}$ & Baik & $\begin{array}{c}\text { Cukup } \\
\text { baik }\end{array}$ \\
\hline Dicky Mardianto & Baik & Baik & $\begin{array}{c}\text { Sangat } \\
\text { Baik }\end{array}$ & Baik & $\begin{array}{c}\text { Cukup } \\
\text { baik }\end{array}$ & $\begin{array}{c}\text { Sangat } \\
\text { Baik }\end{array}$ & $\begin{array}{l}\text { Cukup } \\
\text { baik }\end{array}$ & Baik \\
\hline Putri Shefira R & $\begin{array}{c}\text { Sangat } \\
\text { Baik }\end{array}$ & $\begin{array}{c}\text { Sangat } \\
\text { Baik }\end{array}$ & Baik & $\begin{array}{c}\text { Cukup } \\
\text { baik }\end{array}$ & Baik & Baik & $\begin{array}{c}\text { Cukup } \\
\text { baik }\end{array}$ & Baik \\
\hline Afiansyah Damanik & Baik & Baik & $\begin{array}{c}\text { Sangat } \\
\text { baik }\end{array}$ & Baik & Buruk & $\begin{array}{c}\text { Sangat } \\
\text { baik }\end{array}$ & Baik & Baik \\
\hline Ririn Ocktavia & Baik & Baik & $\begin{array}{c}\text { Sangat } \\
\text { Baik }\end{array}$ & Baik & $\begin{array}{c}\text { Cukup } \\
\text { Baik }\end{array}$ & Buruk & Buruk & $\begin{array}{c}\text { Sangat } \\
\text { Baik }\end{array}$ \\
\hline Feri Irwansyah & Baik & $\begin{array}{c}\text { Sangat } \\
\text { Baik }\end{array}$ & Baik & Baik & Baik & $\begin{array}{c}\text { Sangat } \\
\text { Baik }\end{array}$ & $\begin{array}{c}\text { Sangat } \\
\text { Baik }\end{array}$ & Buruk \\
\hline Armansyah Lubis & $\begin{array}{c}\text { Sangat } \\
\text { Baik }\end{array}$ & Baik & Baik & $\begin{array}{c}\text { Sangat } \\
\text { Baik }\end{array}$ & $\begin{array}{c}\text { Cukup } \\
\text { Baik }\end{array}$ & $\begin{array}{c}\text { Cukup } \\
\text { Baik }\end{array}$ & Baik & Baik \\
\hline Kiki Armi & Baik & Baik & Baik & $\begin{array}{c}\text { Cukup } \\
\text { baik }\end{array}$ & $\begin{array}{c}\text { Sangat } \\
\text { Baik }\end{array}$ & Buruk & Buruk & $\begin{array}{c}\text { Sangat } \\
\text { Baik }\end{array}$ \\
\hline
\end{tabular}


JURNAL MEDIA INFORMATIKA BUDIDARMA

Volume 4, Nomor 3, Juli 2020, Page 612-617

ISSN 2614-5278 (media cetak), ISSN 2548-8368 (media online)

Available Online at https://ejurnal.stmik-budidarma.ac.id/index.php/mib DOI 10.30865/mib.v4i3.2176

\begin{tabular}{ccccccccc}
\hline \multirow{2}{*}{ Alternatif } & \multicolumn{10}{c}{ Kriteria } \\
\cline { 2 - 10 } & L & PKK & KMK & KB & KS & K3 & TJ & D \\
\hline \multirow{2}{*}{ Santo Sidabutar } & Baik & $\begin{array}{c}\text { Sangat } \\
\text { baik }\end{array}$ & Baik & Cukup & Cukup & Cukup & Cukup & Baik \\
Fachri Ramadhan & Buruk & $\begin{array}{c}\text { Sangat } \\
\text { Baik }\end{array}$ & Baik & Buruk & Baik & $\begin{array}{c}\text { Baik } \\
\text { Baik } \\
\text { Baik }\end{array}$ & $\begin{array}{c}\text { Cukup } \\
\text { Baik }\end{array}$ & Baik \\
Abdul Hanif & $\begin{array}{c}\text { Cukup } \\
\text { baik }\end{array}$ & Baik & $\begin{array}{c}\text { Sangat } \\
\text { Baik }\end{array}$ & Baik & Buruk & Baik & Baik & Baik \\
Afdal & $\begin{array}{c}\text { Cukup } \\
\text { baik }\end{array}$ & Baik & $\begin{array}{c}\text { Cukup } \\
\text { Baik }\end{array}$ & Baik & Buruk & Baik & Baik & Baik \\
\hline
\end{tabular}

Tabel 5. Tabel Hasil Vektor $S$

\begin{tabular}{|c|c|c|c|c|c|c|c|c|}
\hline \multirow{2}{*}{ Alternatif } & \multicolumn{8}{|c|}{ Kriteria } \\
\hline & $\mathbf{L}$ & PKK & KMK & KB & KS & K3 & TJ & D \\
\hline Riana & 1,27305012 & 1,11612317 & 1,23114441 & 1,14869835 & 1,14869835 & 1,17914765 & 1,1486984 & 1,23114441 \\
\hline Desi Ismira & 1,27305012 & 1,14869835 & 1,27305012 & 1,14869835 & 1,17461894 & 1,27305012 & 1,1161232 & 1,27305012 \\
\hline Muhammad Ferdi & 1,23114441 & 1,17461894 & 1,27305012 & 1,17461894 & 1,14869835 & 1,10956947 & 1,1161232 & 1,23114441 \\
\hline Raka Aditya & 1,23114441 & 1,14869835 & 1,27305012 & 1,14869835 & 1,11612317 & 1,27305012 & 1,1486984 & 1,17914765 \\
\hline Dicky Mardianto & 1,23114441 & 1,14869835 & 1,27305012 & 1,14869835 & 1,11612317 & 1,27305012 & 1,1161232 & 1,23114441 \\
\hline Putri Shefira R & 1,27305012 & 1,17461894 & 1,23114441 & 1,11612317 & 1,14869835 & 1,23114441 & 1,1161232 & 1,23114441 \\
\hline Ririn Ocktavia & 1,23114441 & 1,14869835 & 1,27305012 & 1,14869835 & 1,11612317 & 1,10956947 & 1,0717735 & 1,27305012 \\
\hline Feri Irwansyah & 1,23114441 & 1,17461894 & 1,23114441 & 1,14869835 & 1,14869835 & 1,27305012 & 1,1746189 & 1,10956947 \\
\hline Armansyah Lubis & 1,27305012 & 1,14869835 & 1,23114441 & 1,17461894 & 1,11612317 & 1,17914765 & 1,1486984 & 1,23114441 \\
\hline Kiki Armi & 1,23114441 & 1,14869835 & 1,23114441 & 1,11612317 & 1,17461894 & 1,10956947 & 1,0717735 & 1,27305012 \\
\hline Santo Sidabutar & 1,23114441 & 1,17461894 & 1,23114441 & 1,11612317 & 1,11612317 & 1,17914765 & 1,1161232 & 1,23114441 \\
\hline Fachri Ramadhan & 1,10956947 & 1,17461894 & 1,23114441 & 1,07177346 & 1,14869835 & 1,27305012 & 1,1161232 & 1,23114441 \\
\hline Abdul Hanif & 1,17914765 & 1,14869835 & 1,27305012 & 1,14869835 & 1,07177346 & 1,23114441 & 1,1486984 & 1,23114441 \\
\hline
\end{tabular}

Tabel 6. Tabel Hasil Vektor V dan Ranking

\begin{tabular}{cccc}
\hline Kode & Nama Alternatif & Vektor V & Rank \\
\hline A1 & Riana & 0,067369472 & 8 \\
A2 & Desi Ismira & 0,079525144 & 1 \\
A3 & Muhammad Ferdi & 0,066287473 & 9 \\
A4 & Raka Aditya & 0,069662595 & 5 \\
A5 & Dicky Mardianto & 0,07067187 & 2 \\
A6 & Putri Shefira R & 0,069887754 & 3 \\
A7 & Afiansyah Damanik & 0,069844359 & 4 \\
A8 & Ririn Ocktavia & 0,06116218 & 13 \\
A9 & Feri Irwansyah & 0,068222139 & 7 \\
A10 & Armansyah Lubis & 0,068889677 & 6 \\
A11 & Kiki Armi & 0,060483576 & 12 \\
A12 & Santo Sidabutar & 0,062896995 & 11 \\
A13 & Fachri Ramadhan & 0,060483576 & 12 \\
A14 & Abdul Hanif & 0,064692513 & 10 \\
A15 & Afdal & 0,059920677 & 14 \\
\hline
\end{tabular}

Dari hasil perangkingan terlihat alternatif A2 yaitu Desi Ismira memiliki nilai kinerja yang tertinggi dan terbaik dibandingkan dengan karyawan yang lain.

\section{KESIMPULAN}

Dari data dan uraian penelitian di atas dapat disimpulkan sebagai berikut:

1. Penilaian terhadap kinerja kerja karyawan ditemukan kualitas dan kuantitas masing-masing karyawan tetap dan hasil yang ditemuka sangat bervarias dengan rentan jarak penilaian yang sedikit, hasil tersebut menunjukan bahwa manajemen perusahaan berhasil dalam manajemen sumber daya manusianya sehingga memiliki tingkat dan kinerja yang baik dan memuaskan.

2. Metode Weighted Product (WP) merupakan metode yang mudah dan sangat singkat dalam pengerjaan langkahlangkah dari metode itu sendiri dan membuat pengerjaan data yang banyak tidak memakan banyak waktu dan lebih efisien, hasil dari metode Weighted Product (WP) diihat dari nilai tertnggi dan dlakukan pemberian rangking atau peringkat terhadap nilai dari terbesar hingga nilai terkecil sehingga dapat dikembangan sistem untuk meningkatkan evaluasi dan minat karyawan terhadap peningkatan kinerja kerja dengan memberi penghargaan (reward) atau bentuk apresiasi lainnya. 
JURNAL MEDIA INFORMATIKA BUDIDARMA

Volume 4, Nomor 3, Juli 2020, Page 612-617

ISSN 2614-5278 (media cetak), ISSN 2548-8368 (media online)

Available Online at https://ejurnal.stmik-budidarma.ac.id/index.php/mib DOI $10.30865 /$ mib.v4i3.2176

\section{REFERENCE}

[1] N. Noviari and J. Akuntansi, "Pengaruh Kemajuan Teknologi Informasi Terhadap Perkembangan Akuntansi," J. Ilm. Akunt. dan Bisnis, pp. 1-14, 2007.

[2] R. Faslah and A. Haris, "Perencanaan Strategis Sistem Informasi," J. ELTIKOM, vol. 1, no. 1, pp. 31-38, 2017.

[3] M. R. Maulana, "Penilaian Kinerja Karyawan Di Ifun Jaya Textile Dengan Metode Fuzzy Simple Additive Weighted," J. Ilm. ICTech, vol. 10, no. 1, pp. 1-12, 2012.

[4] A. H. Rustiawan, Sistem Pendukung Keputusan. 2012

[5] T. Limbong et al., Sistem Pendukung Keputusan: Metode \& Implementasi. Medan: Yayasan Kita Menulis, 2020.

[6] Efraim Turban and Jay E. Aronson, Decision Support System and Intelligent Systems. 2001.

[7] D. I. K. SURYADI and M. T. IR. M. ALI RAMADHANI, SISTEM PENDUKUNG KEPUTUSAN, SISTEM PEN. Bandung: PT Remaja Rosdakarya Bandung, 1998.

[8] A. A. Chamid and A. C. Murti, "Kombinasi Metode Ahp Dan Topsis Pada Sistem Pendukung Keputusan," Pros. SNATIF Ke-4, pp. 115-119, 2017.

[9] S. H. Sahir, R. Rosmawati, and K. Minan, "Simple Additive Weighting Method to Determining Employee Salary Increase Rate," Int. J. Sci. Res. Sci. Technol., vol. 3, no. 8, pp. 42-48, 2017.

[10] D. C. Yoni and H. Mustafidah, “93123-ID-penerapan-metode-wp-weighted-product-unt.pdf,” vol. IV, pp. 22-27, 2016.

[11] Adi Nugroho, Analisis dan Perancangan Sistem Informasi dengan Metodologi Berorientasi Objek. 2005.

[12] S. Kosasi, "Perancangan Sistem E-Commerce Untuk Memperluas Pasar Produk Oleh-Oleh Khas Pontianak," Snastia, vol. 2015, no. Oktober, pp. 110-119, 2015.

[13] D. Prasada, "KREATIF Jurnal Ilmiah Prodi Manajemen Universitas Pamulang, Volume 7, No 1 Juni 2019," Kreat. J. Ilm. Prodi Manaj. Univ. Pamulang, vol. 7, no. 1, pp. 55-65, 2019.

[14] Y. H. Agustin and H. Kurniawan, "Sistem Pendukung Keputusan Dalam Penilaian Kinerja Dosen Menggunakan Metode Weighted Product ( Studi Kasus : Dosen STMIK Balikpapan ),” Semin. Nas. Inform. 2015, vol. 1, no. Snrik, pp. 1-7, 2015 .

[15] A. S. Supriyanto and E. A. Troena, "Pengaruh Kecerdasan Emosional dan Kecerdasan Spritual Terhadap Kepemimpinan Transformasional, Kepuasan Kerja Dan Kinerja Manajer," J. Apl. Manaj., vol. 10, no. 66, pp. 163-5241, 2012.

[16] A. Hafiz, "SISTEM PENDUKUNG KEPUTUSAN PEMILIHAN KARYAWAN TERBAIK DENGAN PENDEKATAN WEIGHTED PRODUCT ( Studi Kasus : PT . Telkom Cab . Lampung ),” vol. XV, no. April, pp. 23-28, 2018. 